\title{
INDEX TO VOLUME 9 (1971)
}

\section{ARTICLES}

Adamolekun, 'Ladipo, 'Bureaucrats and the Senegalese Political Process', $4,543-59$

Aluko, S. A., 'Population Growth and the Level of Income: a survey', 4, $5^{6} \mathbf{I}-75$

Barbour, K. M., 'North-Eastern Nigeria - a case study of state formation', I, 49-7I

'Bureaucrats and the Senegalese Political Process', by 'Ladipo Adamolekun, 4, 543-59

'Colonial Chiefs in Chiefless Societies', by Robert L. Tignor, 3, 339-59.

'The Development of Population Policies', by D. I. Pool, I, $9 \mathrm{I}-\mathrm{I} 05$

'Economic Development and Income Distribution in Eastern Africa', by Dudley Jackson, 4, $53^{\mathrm{I}-42}$

'Effectiveness of Foreign Aid - the case of Somalia', by Ozay Mehmet, I, $31-47$

'Equal Rights for Women in Kenya?', by Audrey Wipper, 3, 429-42

Esseks, JoHN D., 'Government and Indigenous Private Enterprise in Ghana', I, I I -29

'The Expulsion of West African Aliens', by Margaret Peil, 2, 205-29

'Government and Indigenous Private Enterprise in Ghana', by John D. Esseks, I, I I $\rightarrow 29$

Harbeson, John W., 'Land Reforms and Politics in Kenya, 1954-70', 2, $33^{\mathrm{I}-5^{\mathrm{I}}}$

"The Ideology of "Tribalism", by Archie Mafeje, 2, 253-6I

'Indigenous Enterprise in Nigerian Manufacturing', by L. O. Odufalu, 4, $593-607$

Ismael, TAReQ Y., 'The People's Republic of China and Africa', 4, 507-29

'Israel's Military Aid to Africa, 1960-66', by Abel Jacob, 2, 165-87

Jackson, Dudley, 'Economic Development and Income Distribution in Eastern Africa', 4, 53I-42

JAGOB, ABEL, 'Israel's Military Aid to Africa, I96o-66', 2, I65-87

'Land Reforms and Politics in Kenya, 1954-70', by John W. Harbeson, 2, $33^{\mathrm{I}-5^{\mathrm{I}}}$

Landell-Mills, P. M., 'The 1969 Southern African Customs Union Agreement', 2, 263-8I

'Left and Right in Africa', by Immanuel Wallerstein, I, I-10

'Liberia: the dynamics of continuity', by Thomas P. Wrubel, 2, 189-204

MAfEJe, ARChIE, 'The Ideology of "Tribalism", 2, 253-6I

MAGEE, JAmes S., 'What Role for E.C.A.? - or pan-Africanism revisited', I, $73-89$

Menmet, Ozay, 'Effectiveness of Foreign Aid - the case of Somalia', I, $31-47$

'Nigeria's Federal Financial Experience', by Adedotun Phillips, 3, 389-408 
'North-Eastern Nigeria - a case study of state formation', by K. M. Barbour, I, 49-7I

Odufalu, J. O., 'Indigenous Enterprise in Nigerian Manufacturing', 4, 593-607

Peil, Margaret, 'The Expulsion of West African Aliens', 2, 205-29

'The People's Republic of China and Africa', by Tareq Y. Ismael, 4, 507-29

Phillips, Adedotun, 'Nigeria's Federal Financial Experience', 3, 389-408

Pool, D. I., 'The Development of Population Policies', I, 9 $1-105$

'Population Growth and the Level of Income: a survey', by S. A. Aluko, $4,5^{6 I-75}$

'Prospects for Africa's Exports', by Ann Seidman, 3, 409-28

Seidman, Ann, 'Prospects for Africa's Exports', 3, 409-28

'The 1969 Southern African Customs Union Agreement', by P. M. LandellMills, 2, 263-8r

Tignor, Robert L., 'Colonial Chiefs in Chicfless Societies', 3, 339-59

'Urban Government and Nation Building in East Africa', by Richard Vengroff, 4, 577-92

VengrofF, RighaRD, 'Urban Government and Nation Building in East Africa, 4, 577-92

'Wage Policy and the Colonial Legacy - a comparative study', by John F. Weeks, 3, 36r-87

Wallerstein, Immanuer, 'Left and Right in Africa', I, I-IO

Weeks, John F., 'Wage Policy and the Colonial Legacy - a comparative study', 3, 36I-87

'What Role for E.C.A.? - or pan-Africanism revisited', by James S. Magee, $1,73-89$

Wipper, AUdrey, 'Equal Rights for Women in Kenya?', 3, 429-42

Wrubel, Thomas P., 'Liberia: the dynamics of continuity', 2, 189-204

\section{AFRICANA}

African Dance Institute, by Judith Lynne Hanna, 2, 296-7

African Studies Association, Annual Meeting of the (American), by Aaron Segal, I, I37-4I

Callaway, Arghibald, 'Prospects for Employment Opportunities in the I970s', 2, 283-9I

'The Causes of Poverty in the Periphery', by Justinian F. Rweyemamu, 3, 453-5

CoHen, Roвin, 'Nigeria's Central Trade Union Organisation : a study guide', $3,456-8$

'The Commission for Technical Co-operation in Africa, 1950-65', by Isebill V. Gruhn, 3, 459-69

'The Control of Annual Plans: the experience of Tunisia', by J. G. Kleve, 2, 306-10

DAhlBERG, F. M., 'The Emergence of a Dual Governing Elite in Uganda', 4, $618-25$ 
'An Early Nigerian Civil Disturbance: the 1945 Hausa-Ibo riot in Jos', by Leonard Plotnicov, 2, 297-305

EL-Khawas, Mohamed, 'The Third-World Stance on Apartheid: the U.N. record', 3, 443-52

'The Emergence of a Dual Governing Elite in Uganda', by F. M. Dahlberg, 4, 6r 8-25

'Enterprise, Management and Organisation: a plea for research', by J. W. Garmany, 4, 634-9

'From Devil to Father Figure: the transformation of Jomo Kenyatta by Kenya whites', by Peter Knauss, I, I 3 I-7

Garmany, J. W., 'Enterprise, Management, and Organisation: a plea for research', 4, 634-9

GavriLova, A., 'Special Features of Urbanisation in Tropical Africa', 2, $29 I-6$

Grunn, Iserill V., 'The Commission for Technical Co-operation in Africa, I950-65', 3, 459-69

HanNa, Judith LynNe, African Dance Institute, 2, 296-7

Kleve, J. G., 'The Control of Annual Plans: the experience of Tunisia', 2, 306-10

KOOPMAN, JozEPH, and Schmidt, AdAM, 'ANew Partnership for Development', I, II $5-23$

Knauss, Peter, 'From Devil to Father Figure: the transformation of Jomo Kenyatta by Kenya whites', I, I3 I-7

'A New Partnership for Development', by Jozeph Koopman and Adam Schmidt, I, I I 5-23

'Nigeria's Gentral Trade Union Organisation: a study guide', by Robin Cohen, 3, 456-8

Nyerere, Julius K., 'The Role of an African University', I, 107-14

'Party Politics and a Rural Immigrant Community', by A. F. Robertson, I, 124-30

Plotnicov, Leonard, 'An Early Nigerian Civil Disturbance: the 1945 Hausa-Ibo riot in Jos', 2, 297-305

'Prospects for Employment Opportunities in the 1970s', by Archibald Callaway, 2, 283-9r

'Radical African Studies in the United States', by Peter Waterman, 4, 6o9-I I Robertson, A. F., 'Party Politics and a Rural Immigrant Community', I, I24-30

'The Role of an African University', by Julius K. Nyerere, I, 107-14

Rweyemamu, Justinian F., 'The Causes of Poverty in the Periphery', 3, 453-5

SAlgedo, Rodolfo N., 'What Leads to Modernisation?', 4, 626-33

Schmidt, Adam, and Koopman, Jozeph, 'A New Partnership for Development', 1, I I 5-23

Segal, Aaron, Annual Meeting of the (American) African Studies Association, I, 137-4I

'Special Features of Urbanisation in Tropical Africa', by A. Gavrilova, 2, 29 I-6

'The Third-World Stance on Apartheid: the U.N. record', by Mohamed El-Khawas, 3, 443-52 
Triplett, George W., 'Zanzibar: the politics of revolutionary inequality', $4,612-17$

Waterman, Peter, 'Radical African Studies in the United States', 4, 609-I I

'What Leads to Modernisation?', by Rodolfo N. Salcedo, 4, 626-33

'Zanzibar: the politics of revolutionary inequality', by George W. Triplett, $4,612-17$

\section{REVIEWS}

L'Accumulation à l'échelle mondiale: critique de la théorie du sous-développement by Samir Amin, reviewed by Frederick F. Clairmonte, 3, 480-2

The Administration of Nigeria, 1900-1960: men, methods, and myths by I. F. Nicolson, reviewed by J. A. Ballard, I, I 53-6

Africa and its Explorers: motives, methods, and impact edited by Robert I. Rotberg, reviewed by Lenwood G. Davis, 4, 649-50

Africa from Early Times to 1800 , Vol. I of Readings in African History edited by P. J. M. McEwan, reviewed by P. B. Harris, 3, 482-3

Africa to 1875 by Robin Hallett, reviewed by Erving E. Beauregard, 2, 312-1 5 African Perspectives: papers in the history, politics and economics of Africa presented to Thomas Hodgkin edited by Christopher Allen and R. W. Johnson, reviewed by Richard L. Sklar, 3, 47 I-4

An African School: a record of experience by Kit Elliott, reviewed by R. A. G. Pearce, I, 163-4

The African Voice in Southern Rhodesia, $1898-1930$ by T. O. Ranger, reviewed by Donald Denoon, 2, 32 I-4

Allen, Christopher, and Johnson, R. W. (eds.), African Perspectives: papers in the history, politics and economics of Africa presented to Thomas Hodgkin, reviewed by Richard L. Sklar, 3, 47I-4

Amin, SAmtr, L'Accumulation à l'échelle mondiale: critique de la théorie du sousdéveloppement, reviewed by Frederick F. Clairmonte, 3, 480-2

ANDERson, JoHN, The Struggle for the School: the interaction of missionary, colonial government and nationalist enterprise in the development of formal education in Kenya, reviewed by Roger van Zwanenberg, 3, 493-5

Asad, TALAL, The Kababish Arabs: power, authority and consent in a nomadic tribe, reviewed by R. E. S. Tanner, $4,665-6$

Ashley, Mrchael, review of When Boys were Men edited by Guy Butler, 3, $495^{-6}$

L'Association à la Communauté économique européenne: aspects juridiques by l'Institut d'études européennes, reviewed by Carol Ann Cosgrove, I, I6o-2

Axnor, H. S., Notes from Africa, reviewed by Kenneth J. Twitchett, I, $14^{8-50}$

BaER, Gabrier, Studies in the Social History of Modern Egypt, reviewed by Warren L. Young, I, I58-6o

Ballard, J.A., review of The Administration of Nigeria, 1900-1960: men, methods, and myths by I. F. Nicolson, and of Lugard and the Amalgamation of Nigeria: a documentary record compiled and introduced by A. H. M. Kirk-Greene, I, $153^{-6}$ 
BARBer, JAMEs, Imperial Frontier: a study of relations between the British and the pastoral tribes of $\mathcal{N o r t h ~ E a s t ~ U g a n d a , ~ r e v i e w e d ~ b y ~ M a i n a ~ K a g o m b e , ~ 3 , ~}$ $487-90$

Beauregard, Erving E., review of France and West Africa: an anthology of historical documents edited by John D. Hargreaves, of Africa to 1875 by Robin Hallett, and of Problems in the History of Colonial Africa, 1860-1960 edited by Robert $O$. Collins, 2, 312-15

Betz, F. H., Entwicklungshilfe an Afrika, reviewed by Carol Ann Cosgrove, $4,65^{\mathrm{I}-2}$

Bley, Helmut, South-West Africa under German Rule, 1894-1914, translated and edited by Hugh Ridley, reviewed by Ibrahim A. Gambari, 3, 484-6

Brooks, Hugh C., and El-Ayouty, YAssin (eds.), Refugees South of the Sahara: an African dilemma, reviewed by I. William Zartman, 2, 31 1-I 2

Butler, Guy, (ed.), When Boys were Men, reviewed by Michael Ashley, 3, 495-6

Carey Francis of Kenya by L. B. Greaves, reviewed by Roger van Zwanenberg, 2, 333-5

Cartwright, John R., Politics in Sierra Leone, 1947-67, reviewed by Robert E. Johnston, 2, 329-3I

Cattle and Kinship among the Gogo: a semi-pastoral society of Central Tanzania by Peter Rigby, reviewed by R. E. S. Tanner, 4, 665-6

Caulk, Richard A., review of Economic History of Ethiopia, 1800-1935 by Richard Pankhurst, 3, 490-2

Caute, David, Frantz Fanon, reviewed by Tony Martin, 2, 335-7

Chambers, Robert, Settlement Schemes in Tropical Africa: a study of organizations and development, reviewed by A. H. Hanson, I, I $43-6$

Chambers, Robert (ed.), The Volta Resettlement Experience, reviewed by A. H. Hanson, I, I43-6

Chief, Council and Commissioner: some problems of government in Rhodesia by J. F. Holleman, reviewed by John Day, 4, 655-6

City Politics: a study of Léopoldville, $1962-6_{3}$ by J. S. La Fontaine, reviewed by Kenneth Little, 4, 667-70

Glairmonte, Frederick F., review of L'Accumulation d l'échelle mondiale: critique de la théorie du sous-développement by Samir Amin, 3, 480-2

Clapham, Christopher, Haile-Selassie's Government, reviewed by James C. N. Paul, 3, 498-505

Class and Colour in South Africa, 1850-1950 by H. J. and R. E. Simons, reviewed by Graham C. Kinloch, 4, 66I-3

Clayton, Anthony, review of Development and Planning in Tanzania by Abdul Khakee, 2, 3I $5^{-16}$

Collins, Robert O. (ed.), Problems of the History of Colonial Africa, 1860-1960, reviewed by Erving E. Beauregard, 2, 312-I 5

Colonialism in Africa, 1870-196o, Vol. 2, The History and Politics of Colonialism, 1914-1960 edited by L. H. Gann and Peter Duignan, reviewed by Semakula Kiwanuka, 4, 644-7

Colonial Sequence, 1949-1969 by Margery Perham, reviewed by P. B. Harris, $4,647-9$ 
La Communauté et le tiers monde by l'Institut d'études européennes, reviewed by Carol Ann Cosgrove, I, I60-2

Cosgrove, Carol Ann, review of A Foreign Policy for Europe? by Gordon L. Weil, of La Communauté et le tiers monde by l'Institut d'études européennes, and of L'Association à la Communauté économique européenne: aspects juridiques by l'Institut d'études européennes, 1, I 6o-2

- review of The Politics of Trade Negotiations between Africa and the European Economic Community: the weak confront the strong by I. William Zartman, and of Entwicklungshilfe an Afrika edited by F. H. Betz, 4, $65^{1-2}$

Crisis in Rhodesia by Nathan Shamuyarira, reviewed by Donald Denoon, 2, $321-4$

DAvis, LeNwood G., review of Africa and its Explorers: motives, methods and impact edited by Robert I. Rotberg, 4, 649-50

DAY, JoHN, review of Rhodesia: a human geography by George Kay, of Chief, Council and Commissioner: some problems of government in Rhodesia by J. F. Holleman, of The Governmental System in Southern Rhodesia by D.J. Murray, and of Flame or Lily? by Graham C. Kinloch, 4, 655-7

Decalo, Samued, review of Israeli Technical Assistance to African Countries by Jehudi J. Kanarek, I, I62-3

De Gregori, Thomas R., Technology and the Economic Development of the Tropical African Frontier, reviewed by Alan Rufus Waters, 3, 479-80

Deng, Francis Mading, Tradition and Modernization: a challenge for law among the Dinka of the Sudan, reviewed by James J. Fishman, 4, 663-4

Denoon, Donald, review of The African Voice in Southern Rhodesia, 1898-1930 by T. O. Ranger, of Origins of Rhodesia by Stanlake Samkange, and of Crisis in Rhodesia by Nathan Shamuyarira, 2, 321-4

Development and Planning in Tanzania by Abdul Khakee, reviewed by Anthony Clayton, 2, 315-16

DoBb, MAURIcE, Welfare Economics and the Economics of Socialism: towards a commonsense critique, reviewed by A. F. Ewing, 2, 332-3

Duignan, Peter, and Gann, L. H. (eds.), Colonialism in Africa, 1870-1960, Vol. 2, The History and Politics of Colonialism, 1914-1960, reviewed by Semakula Kiwanuka, 4, 644-7

East Africa: its peoples and resources edited by W. T. W. Morgan, reviewed by Matthias A. Ogutu, 3, 496-8

Economic Development in Egypt by Bent Hansen, reviewed by Warren L. Young, $1,15^{8-60}$

Economic History of Ethiopia, ${ }^{800-1935}$ by Richard Pankhurst, reviewed by Richard A. Caulk, 3, 490-2

The Economies of Africa edited by P. Robson and D. Lury, reviewed by F. Akin Olaloku, 4, 653-4

Education since Uhuru: the schools of Kenya by Ernest Stabler, reviewed by Roger van Zwanenberg, 3, 493-5

Eicher, CARL K., and Liedholm, Carl (eds.), Growth and Development of the Nigerian Economy, reviewed by G. O. Nwankwo, 2, 31 8-2 I

El-Ayouty, Yassin, and Brooks, Hugh C. (eds.), Refugees South of the Sahara: an African dilemma, reviewed by I. William Zartman, 2, 31 I-12 
EleazU, UMa O., review of The New Nations in the United Nations: 1960-1967 by David A. Kay, and of Nonaligned Black Africa by George W. Shepherd, $4,64 \mathrm{I}-3$

ElliotT, KrT, An African School: a record of experience, reviewed by R. A. G. Pearce, I, I63-4

Entwicklungshilfe an Afrika edited by F. H. Betz, reviewed by Carol Ann Cosgrove, $4,65^{\mathrm{I}-2}$

Ethiopia: the modernization of autocracy by Robert L. Hess, reviewed by James C. N. Paul, 3, 498-505

Ewing, A. F., review of Industrialization in an Open Economy: Nigeria, 1945-1966 by Peter Kilby, and of Exports and Economic Growth of Developing Countries by $A$. Maizels, I, I50-3

review of Welfare Economics and the Economics of Socialism: towards a commonsense critique by Maurice Dobb, 2, 332-3

Exports and Economic Growth of Developing Countries by A. Maizels, reviewed by A. F. Ewing, I, I 50-3

Fanon by Peter Geismar, reviewed by Tony Martin, 2, 335-7

Fishman, James J., review of Tradition and Modernization: a challenge for law among the Dinka of the Sudan by Francis Mading Deng, and of The Legal System of Ethiopia by Kenneth R. Redden, 4, 663-4

Flame or Lily? by Graham C. Kinloch, reviewed by John Day, 4, 655-7

A Foreign Policy for Europe? by Gordon L. Weil, reviewed by Carol Ann Cosgrove, $1,160-2$

France and West Africa: an anthology of historical documents edited by John D. Hargreaves, reviewed by Erving E. Beauregard, 2, 31 2-I 5

Frantz Fanon by David Caute, reviewed by Tony Martin, 2, 335-7

The Freemen of Meru by Anton Nelson, reviewed by Maina Kagombe 3, 487-9o

Froelich, J.-G. (ed.), Le Problème des réfugiés en Afrique, reviewed by I. William Zartman, 2, 31 I-I2

Galied, Ali Khalif, review of Violence and Thought: essays on social tensions in Africa by Ali A. Mazrui, I, 146-8

Gambari, Ibrahim A., review of South-West Africa under German Rule, 18941914 by Helmut Bley, translated and edited by Hugh Ridley, and of South-West Africa (Namibia): proposals for action edited by Richard Hall, 3 , 484-6

Gann, L. H., and Duignan, Peter (eds.), Colonialism in Africa, 1870-1960, Vol. 2, The History of Politics of Colonialism, 1914-1960, reviewed by Semakula Kiwanuka, 4, 644-7

Geismar, Peter, Fanon, reviewed by Tony Martin, 2, 335-7

Ghat, Y. P., and McAuslan, J. P. W. B., Public Law and Political Change in Kenya: a study of the legal framework of government from colonial times to the present, reviewed by Robert Martin, 2, 324-6

Gitelson, Susan Aurelia, review of Planning Processes: the East African case by Rolf E. Vente, 2, 316-18

The Government of Ethiopia by Margery Perham, reviewed by James C. N. Paul, 3, 498-505

The Governmental System in Southern Rhodesia by D. J. Murray, reviewed by John Day, 4, 655-7 
The Great Powers and Africa by Waldemar A. Nielsen, reviewed by Kenneth J. Twitchett, I, 148-50

Greaves, L. B., Carey Francis of Kenya, reviewed by Roger van Zwanenberg, $2,333-5$

Green, Reginald Herbold, review of Wage Policy Issues in Economic Development edited by Anthony D. Smith, 3, 476-9

Growth and Development of the Nigerian Economy edited by Carl K. Eicher and Carl Liedholm, reviewed by G. O. Nwankwo, 2, 318-2I

Haile-Selassie's Government by Christopher Glapham, reviewed by James C. N. Paul, 3, 498-505

Hall, Richard (ed.), South-West Africa (Namibia): proposals for action, reviewed by Ibrahim A. Gambari, 3, 484-6

Hallett, Robin, Africa to 1875, reviewed by Erving E. Beauregard, 2, 312-I 5 Hamrell, Sven (ed.), Refugee Problems in Africa, reviewed by I. William Zartman, 2, 3II-I 2

Hansen, Bent, Economic Development in Egypt, reviewed by Warren L. Young, I, I 58-60

Hanson, A. H., review of Modernizing Peasant Societies: a comparative study in Asia and Africa by Guy Hunter, of The Volta Resettlement Experience edited by Robert Chambers, and of Settlement Schemes in Tropical Africa: a study of organizations and development by Robert Chambers, I, ${ }_{43}^{-6}$

Hargreaves, John D. (ed.), France and West Africa: an anthology of historical documents, reviewed by Erving E. Beauregard, 2, 31 2-I5

Harris, P. B., review of Readings in African History: Vol. I, Africa from Early Times to 180o; Vol. 2, Nineteenth-Century Africa; Vol. 3, Twentieth-Century History edited by P. J. M. McEwan, 3, $482-3$

- review of Colonial Sequence, 1949-1969 by Margery Perham, 4, 647-9

Harry Thuku: an autobiography with assistance from Kenneth King, reviewed by Roger van Zwanenberg, 2, 333-5

Hess, Robert L., Ethiopia: the modernization of autocracy, reviewed by James C. N. Paul, 3, 498-505

The History and Politics of Colonialism, 1914-1960, Vol. 2 of Colonialism in Africa, $1870-1960$ edited by L. H. Gann and Peter Duignan, reviewed by Semakula Kiwanuka, 4, 644-7

Holleman, J. F., Chief, Council and Commissioner: some problems of government in Rhodesia, reviewed by John Day, 4, 655-7

Humes, Samuel, review of Politics and Change in Developing Countries edited by Colin Leys, and of Studies in Nigerian Administration edited by D. J. Murray, 3, 474-6

Hunter, Guy, Modernizing Peasant Societies: a comparative study in Asia and Africa, reviewed by A. H. Hanson, I, I43-6

Imperial Frontier: a study of relations between the British and the pastoral tribes of North East Uganda by James Barber, reviewed by Maina Kagombe,3,487-90

Industrialization in an Open Economy: Nigeria, 1945-1966 by Peter Kilby, reviewed by A. F. Ewing, I, I 50-3

Industriearbeit und Kulturwandel in Nigeria: Kulturelle Implikationen des Wandels von einer traditionellen Stammesgesellschaft zu einer modernen Industriegeesllschaft by Hans Dieter Seibel, reviewed by Wieland W. Jaeger, I, I56- 8 
Institut d'études européennes, L'Association à la Communauté économique européenne: aspects juridiques, reviewed by Carol Ann Cosgrove, I, I60-2

Institut d'études européennes, La Communauté et le tiers monde, reviewed by Carol Ann Cosgrove, I, I6o-2

An Introduction to Law in French-Speaking Africa, Vol. I, Africa South of the Sahara by Jeswald W. Salacuse, reviewed by Kwame Opoku, 2, 327-9

Israeli Technical Assistance to African Countries by Jehudi J. Kanarek, reviewed by Samuel Decalo, I, I62-3

JAEger, WiEland W., review of Industriearbeit und Kulturwandel in Nigeria: Kulturelle Implikationen des Wandels von einer traditionellen Stammesgesellschaft zu einer modernen Industriegesellschaft by Hans Dieter Seibel, I, I $56-8$

Johnson, R. W., and Allen, Christopher (eds.), African Perspectives: papers in the history, politics and economics of Africa presented by Thomas Hodgkin, reviewed by Richard L. Sklar, 3, 47 I-4

Johnston, Robert E., review of The Spatial Dynamics of Modernization in Sierra Leone: structure, diffusion, and response by J. Barry Riddell, and of Politics in Sierra Leone, 1947-67 by John R. Cartwright, 2, 329-3I

The Kababish Arabs: power, authority and consent in a nomadic tribe by Talal Asad, reviewed by R. E. S. Tanner, 4, 665-6

Kagombe, Maina, review of Imperial Frontier: a study of relations between the British and the pastoral tribes of North East Uganda by James Barber, of Origins of European Settlement in Kenya by M. P. K. Sorrenson, and of The Freemen of Meru by Anton Nelson, 3, 487-9o

Kanarek, Jehudi J., Israeli Technical Assistance to African Countries, reviewed by Samuel Decalo, I, I62-3

Kay, David A., The New Nations in the United Nations: 1960-1967, reviewed by Uma O. Eleazu, 4, 64I-3

KAy, George, Rhodesia: a human geography, reviewed by John Day, 4, 655-7

Kerr, Malcolm H., The United Arab Republic: the domestic, political, and economic background of foreign policy, reviewed by Warren L. Young, I, I 58-60

Khakee, Abdul, Development and Planning in Tanzania, reviewed by Anthony Clayton, 2, 3 I $5^{-16}$

Kilby, Peter, Industrialization in an Open Economy: Nigeria, 1945-1966, reviewed by A. F. Ewing, I, I50-3

Kinloch, Graham C., review of Race among Nations: a conceptual approach edited by George W. Shepherd and Tilden J. Lemelle, of Race Relations in Sociological Theory by John Rex, of Class and Colour in South Africa, 1850$195^{\circ}$ by J. H. and R. E. Simons, and of Passing for White: a study of racial assimilation in a South African school by Graham Watson, 4, 66I-3 Flame or Lily?, reviewed by John Day, 4, 655-7

KIRK-GReene, A. H. M. (compiled and introduced by), Lugard and the Amalgamation of Nigeria: a documentary record, reviewed by J. A. Ballard, I, I 53-6

Kimanuka, Semakula, review of Colonialism in Africa, 1870-1960, Vol. 2, The History and Politics of Colonialism, $1914-1960$ edited by L. H. Gann and Peter Duignan, 4, 644-7

Klinghoffer, Arthur J., Soviet Perspectives on African Socialism, reviewed by Kenneth J. Twitchett, I, I 48-50 
Kwame Kkrumah: the anatomy of an African dictatorship by Peter Omari, reviewed by Jitendra Mohan, 4, 657-6o

La Fontaine, J. S., City Politics: a study of Léopoldville, $1962-63$, reviewed by Kenneth Little, 4, 667-7o

The Legal System of Ethiopia by Kenneth R. Redden, reviewed by James J. Fishman, 4, 663-4

Lemelle, Tilden J., and Shepherd, George W. (eds.), Race among Nations: a conceptual approach, reviewed by Graham C. Kinloch, 4, 66I-3

Leys, Colin (ed.), Politics and Change in Developing Countries, reviewed by Samuel Humes, 3, 474-6

Lredholm, Garl, and Eicher, Garl K. (eds.), Growth and Development of the Nigerian Economy, reviewed by G. O. Nwankwo, 2, 3I8-2 I

Little, Kenneth, review of City Politics: a study of Léopoldville, $1962-63$ by J. S. La Fontaine, 4, 667-70

Lugard and the Amalgamation of Nigeria: a documentary record compiled and introduced by A. H. M. Kirk-Greene, reviewed by J. A. Ballard, I, I53-6

Lury, D., and Robson, P. (eds.), The Economies of Africa, reviewed by F. Akin Olaloku, 4, 653-4

Maizels, A., Exports and Economic Growth of Developing Countries, reviewed by A. F. Ewing, I, 150-3

The Majangir: ecology and society of a south-west Ethiopian people by Jack Stauder, reviewed by R. E. S. Tanner, $4,66_{5-6}$

Martin, Robert, review of Public Law and Political Change in Kenya: a study of the legal framework of government from colonial times to the present by Y. P. Ghai and J. P. W. B. McAuslan, 2, 324-6

Martin, Tony, review of Fanon by Peter Geismar, and of Frantz Fanon by David Caute, 2, 335-7

Mazrui, Ali A., Violence and Thought: essays on social tensions in Africa, reviewed by Ali Khalif Galied, I, I46-8

McAuslan, J. P. W. B., and GhaI, Y. P., Public Law and Political Change in Kenya: a study of the legal framework of government from colonial times to the present, reviewed by Robert Martin, 2, 324-6

MaEwan, P. J. M. (ed.), Readings in African History: Vol. I, Africa from Early Times to 180o; Vol. 2, Nineteenth-Century Africa; Vol. 3, Twentieth-Century History, reviewed by P. B. Harris, 3, 482-3

Modernizing Peasant Societies: a comparative study in Asia and Africa by Guy Hunter, reviewed by A. H. Hanson, I, I43-6

Mohan, Jitendra, review of Kwame Nkrumah: the anatomy of an African dictatorship by T. Peter Omari, and of Uses and Abuses of Political Power: a case study of continuity and change in the politics of Ghana by Maxwell Owusu, $4,657-60$

Morgan, W. T. W. (ed.), East Africa: its peoples and resources, reviewed by Matthias A. Ogutu, 3, 496-8

Murray, D. J. (ed.), Studies in Nigerian Administration, reviewed by Samuel Humes, 3, 474-6

Murray, D. J., The Governmental System in Southern Rhodesia, reviewed by John Day, 4, 655-7

Nelson, ANTon, The Freemen of Meru, reviewed by Maina Kagombe, 3, 487-9o 
The New Nations in the United Nations: $1960-1967$ by David A. Kay, reviewed by Uma O. Eleazu, 4, 641-3

Nicolson, I. F., The Administration of Nigeria, 1900-1960: men, methods, and myths, reviewed by J. A. Ballard, I, I53-6

Nielsen, Waldemar A., The Great Powers and Africa, reviewed by Kenneth J. Twitchett, I, I 48-50

Nineteenth-Century Africa, Vol. 2 of Readings in African History edited by P. J. M. McEwan, reviewed by P. B. Harris, 3, 482-3

Nonaligned Black Africa by George W. Shepherd, reviewed by Uma O. Eleazu, 4, 641-3

Notes from Africa by H. S. Aynor, reviewed by Kenneth J. Twitchett, I, $14^{8-50}$

Nwankwo, G. O., review of Growth and Development of the Nigerian Economy edited by Carl K. Eicher and Carl Liedholm, 2, 318-21

Ogutu, Matthias A., review of East Africa: its peoples and resources edited by W. T. W. Morgan, 3, 496-8

Olaloku, F. Akin, review of The Economies of Africa edited by P. Robson and D. Lury, 4, 653-4

Omari, T. Peter, Kwame Nkrumah: the anatomy of an African dictatorship, reviewed by Jitendra Mohan, 4, 657-60

Opoku, Kwame, review of An Introduction to Law in French-Speaking Africa, Vol. I, Africa South of the Sahara by Jeswald W. Salacuse, 2, 327-9

Origins of European Settlement in Kenya by M. P. K. Sorrenson, reviewed by Maina Kagombe, 3, 487-90

Origins of Rhodesia by Stanlake Samkange, reviewed by Donald Denoon, 2, 32 I-4

Owusu, Maxweld, Uses and Abuses of Political Power: a case study of continuity and change in the politics of Ghana, reviewed by Jitendra Mohan, 4, 657-6o

Pankhurst, Righard, Economic History of Ethiopia, 1800-1935, reviewed by Richard A. Caulk, 3, 490-2

Passing for White: a study of racial assimilation in a South African school by Graham Watson, reviewed by Graham C. Kinloch, 4, 66I-3

Paul, James C. N., review of The Government of Ethiopia by Margery Perham, of Haile-Selassie's Government by Christopher Clapham, and of Ethiopia: the modernization of autocracy by Robert L. Hess, 3, 498-505

Pearce, R. A. G., review of An African School: a record of experience by Kit Elliott, I, I63-4

Perham, Margery, The Government of Ethiopia, reviewed by James C. N. Paul, 3, 498-505

- Colonial Sequence, 1949-1969, reviewed by P. B. Harris, 4, 647-9

Planning Processes: the East African case by Rolf E. Vente, reviewed by Susan Aurelia Gitelson, 2, 316-18

Politics and Change in Developing Countries edited by Colin Leys, reviewed by Samuel Humes, 3, 474-6

Politics in Sierra Leone, 1947-67 by John R. Cartwright, reviewed by Robert E. Johnston, 2, 329-3I

The Politics of Trade Negotiations between Africa and the European Economic Community: the weak confront the strong by I. William Zartman, reviewed by Carol Ann Cosgrove, 4, 65I-2 
Le Problème des réfugiés en Afrique edited by J.-C. Froelich, reviewed by $\mathrm{I}$. William Zartman, 2, 3 I I-I 2

Problems in the History of Colonial Africa, 1860-1960 edited by Robert O. Collins, reviewed by Erving E. Beauregard, 2, 312-15

Public Law and Political Change in Kenya: a study of the legal framework of government from colonial times to the present by Y. P. Ghai and J. P. W. B. McAuslan, reviewed by Robert Martin, 2, 324-6

Race among Nations: a conceptual approach edited by George W. Shepherd and Tilden J. Lemelle, reviewed by Graham C. Kinloch, 4, 66r-3

Race Relations in Sociological Theory by John Rex, reviewed by Graham C. Kinloch, 4, 66I-3

Ranger, T. O., The African Voice in Southern Rhodesia, 1898-1930, reviewed by Donald Denoon, 2, $32 \mathrm{I}-4$

Readings in African History: Vol. 1, Africa from Early Times to 1800; Vol. 2, Nineteenth-Century Africa; Vol. 3, Twentieth-Century History edited by P. J. M. McEwan, reviewed by P. B. Harris, 3, 482-3

Redden, Kenneth R., The Legal System of Ethiopia, reviewed by James J. Fishman, 4, 663-4

Refugee Problems in Africa edited by Sven Hamrell, reviewed by I. William Zartman, 2, 3 I I-I 2

Refugees South of the Sahara: an African dilemma edited by Hugh C. Brooks and Yassin EI-Ayouty, reviewed by I. William Zartman, 2, 3 I I-I 2

REx, JoHn, Race Relations in Sociological Theory, reviewed by Graham C. Kinloch, 4, 66I-3

Rhodesia: a human geography by George Kay, reviewed by John Day, 4, 655-7

Riddell, J. BARry, The Spatial Dynamics of Modernization in Sierra Leone: structure, diffusion, and response, reviewed by Robert E. Johnston, 2, 329-3 I

Rigby, Peter, Cattle and Kinship among the Gogo: a semi-pastoral society of Central Tanzania, reviewed by R. E. S. Tanner, 4, 665-6

Robson, P., and LuRY, D. (eds.), The Economies of Africa, reviewed by F. Akin Olaloku, 4, 653-4

Rotberg, Robert I. (ed.), Africa and its Explorers: motives, methods and impact, reviewed by Lenwood G. Davis, 4, 649-50

Salacuse, Jeswald W., An Introduction to Law in French-Speaking Africa, Vol. I, Africa South of the Sahara, reviewed by Kwame Opoku, 2, 327-9

Samkange, Stanlake, Origins of Rhodesia, reviewed by Donald Denoon, 2, $32 \mathrm{I}-4$

Seibel, Hans Dieter, Industriearbeit und Kulturwandel in Nigeria: Kulturelle Implikationen des Wandels von einer traditionellen Stammesgesellschaft zu einer modernen Industriegesellschaft, reviewed by Wieland W. Jaeger, I, I 56-8

Settlement Schemes in Tropical Africa: a study of organizations and development by Robert Chambers, reviewed by A. H. Hanson, I, I 43-6

ShamuYarira, Nathan, Crisis in Rhodaria, reviewed by Donald Denoon, 2, $3^{2} \mathrm{I}-4$

Shepherd, George W., Nonaligned Black Africa, reviewed by Uma O. Eleazu, 4, 64I-3

Shepherd, George W., and Lemelle, Trlden J. (eds.), Race among Nations: a conceptual approach, reviewed by Graham C. Kinloch, 4, 66I-3 
Simons, H. J. and R. E., Class and Colour in South Africa, 1850-1950, reviewed by Graham C. Kinloch, 4, 66I-3

Sklar, Richard L., review of African Perspectives: papers in the history, politics and economics of Africa presented to Thomas Hodgkin edited by Christopher Allen and R. W. Johnson, 3, 47I-4

Smith, Anthony D. (ed.), Wage Policy Issues in Economic Development, reviewed by Reginald Herbold Green, 3, 476-9

Sorrenson, M. P. K., Origins of European Settlement in Kenya, reviewed by Maina Kagombe, 3, 487-9o

South-West Africa (Namibia): proposals for action edited by Richard Hall, reviewed by Ibrahim A. Gambari, 3, 484-6

South-West Africa under German Rule, 1894-1914 by Helmut Bley, translated and edited by Hugh Ridley, reviewed by Ibrahim A. Gambari, 3, 484-6

Soviet Perspectives on African Socialism by Arthur J. Klinghoffer, reviewed by Kenneth J. Twitchett, I, I48-50

The Spatial Dynamics of Modernization of Sierra Leone: structure, diffusion, and response by J. Barry Riddell, reviewed by Robert E. Johnston, 2, 329-3I

Stabler, ERnest, Education since Uhuru: the schools of Kenya, reviewed by Roger van Zwanenberg, 3, 439-5

STAUDER, JAGK, The Majangir: ecology and society of a south-west Ethiopian people, reviewed by R. E. S. Tanner, $4,66_{5}-6$

The Struggle for the School: the interaction of missionary, colonial government and nationalist enterprise in the development of formal education in Kenya by John Anderson, reviewed by Roger van Zwanenberg, 3, 493-5

Studies in Nigerian Administration edited by D. J. Murray, reviewed by Samuel Humes, 3, 474-6

Studies in the Social History of Modern Egypt by Gabriel Baer, reviewed by Warren L. Young, I, I 58-6o

TANNER, R. E. S., review of The Kababish Arabs: power, authority and consent in a nomadic tribe by Talal Asad, of Cattle and Kinship among the Gogo: a semi-pastoral society of Central Tanzania by Peter Rigby, and of The Majangir: ecology and society of a south-west Ethiopian people by Jack Stauder, $4,665-6$

Technology and the Economic Development of the Tropical African Frontier by Thomas R. De Gregori, reviewed by Alan Rufus Waters, 3, 479-80

Tradition and Modernization: a challenge for law among the Dinka of the Sudan by Francis Mading Deng, reviewed by James J. Fishman, 4, 663-4

Twentieth-Century History, Vol. 3 of Readings in African History edited by P. J. M. McEwan, reviewed by P. B. Harris, 3, 482-3

Twitchett, Kenneth J., review of Notes from Africa by H. S. Aynor, of The Great Powers and Africa by Waldemar A. Nielson, and of Soviet Perspectives on African Socialism by Arthur J. Klinghoffer, 1, 148-50

The United Arab Republic: the domestir political, and economic background of foreign policy by Malcolm H. Kerr, reviewed by Warren L. Young, I, I 58-6o

Uses and Abuses of Political Power: a case study of continuity and change in the politics of Ghana by Maxwell Owusu, reviewed by Jitendra Mohan, 4, 657-6o

Vente, Rolf E., Planning Processes: the East African case, reviewed by Susan Aurelia Gitelson, 2, 316-18 
Violence and Thought: essays on social tensions in Africa by Ali A. Mazrui, reviewed by Ali Khalif Galied, 1, I46-8

The Volta Resettlement Experience edited by Robert Chambers, reviewed by A. H. Hanson, I, I43-6

Wage Policy Issues in Economic Development edited by Anthony D. Smith, reviewed by Reginald Herbold Green, 3, 476-9

Waters, Alan Rufus, review of Technology and the Economic Development of the Tropical African Frontier by Thomas R. De Gregori, 3, 479-80

WAtson, Graham, Passing for White: a study of racial assimilation in a South African School, reviewed by Graham C. Kinloch, 4, 66I-3

Weil, Gordon L., A Foreign Policy for Europe?, reviewed by Carol Ann Cosgrove, I, I6o-2

Welfare Economics and the Economics of Socialism: towards a commonsense critique by Maurice Dobb, reviewed by A. F. Ewing, 2, 332-3

When Boys were Men edited by Guy Butler, reviewed by Michael Ashley, 3, 495-6

Young, Warren L., review of Studies in the Social History of Modern Egypt by Gabriel Baer, of The United Arab Republic: the domestic, political, and economic background of foreign policy by Malcolm H. Kerr, and of Economic Development in Egypt by Bent Hansen, 1, I 58-60

Zartman, I. William, review of Refugees South of the Sahara: an African dilemma edited by Hugh C. Brooks and Yassin El-Ayouty, of Refugee Problems in Africa edited by Sven Hamrell, and of Le Problème des réfugiés en Afrique edited by J.-C. Froelich, 2, 3 I I-12

Zartman, I. Wrlliam, The Politics of Trade Negotiations between Africa and the European Economic Community: the weak confront the strong, reviewed by Carol Ann Cosgrove, 4, 651-2

van ZWANENBERG, Roger, review of Carey Francis of Kenya by L. B. Greaves, and of Harry Thuku: an autobiography with assistance from Kenneth King, 2, 333-5

review of The Struggle for the School: the interaction of missionary, colonial government and nationalist enterprise in the development of formal education in Kenya by John Anderson, and of Education since Uhuru: the schools of Kenya by Ernest Stabler, 3, 493-5 


\section{Population Geography and Developing Countries}

J. I. Clarke

Depicts the broad patterns in the population geography of developing countries and the way in which they differ from developed countries. 292 pp *£1.75/£2.25

\section{The Geography of Tropical African Development} A. M. O'Connor

An examination of the spatial pattern of economic development in presentday tropical Africa with an analysis of general trends, organised by topic rather than region.

$224 p p \quad * \notin 1.90 / £ 3$

\section{Adult Education in Developing Countries} E. K. Townsend Coles

A comprehensive picture of adult education and guidance in the provision of further opportunities for individual advancement. This description of the theory and practice of adult education in developing countries offers suggestions which, after adaptation, are appropriate throughout the world. $158 \mathrm{pp} *$ E1/E1.50

\section{African Development in Europe J. Burley and P. Tregear}

The proceedings of a Seminar whose main purpose was to examine the role and function of Europe in a developing Africa by means of papers from speakers engaged at close quarters in specific areas of Afro-European co-operation.

$148 p p \quad * f 1.50 / £ 2$

\section{Society, Schools and Progress in Tanzania} J. Cameron and W. A. Dodd

Education is examined against the social, political, economic and historical background of Tanzania.

$266 p p \quad * E 1.40 / £ 2$

\section{Poetry from Africa}

\section{H. Sergeant (Editor)}

This book presents the work of the best new poets in Africa: Gabriel Okara of Nigeria, Gaston Bart-Williams of Sierra Leone, Kwesi Brew of Ghana and David Rubadiri of Malawi.

$108 p \rho \quad 40 p$

* First price: flexi cover Second price: hard cover

For further details or inspection copies please apply to

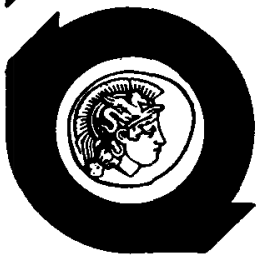
College Department PERGAMON PRESS LIMITED Headington Hill Hall, Oxford OX3 OBW, England

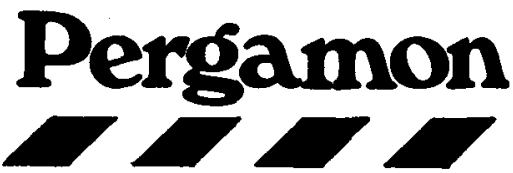




\section{African Perspectives}

Edited by CHRISTOPHER ALLEN and R. W. JOHNSON

A selection from the papers in the history, politics and economics of Africa presented to Thomas Hodgkin on his sixtieth birthday. $£ 5.25$ net

From a five-volume collaborative history

\section{Colonialism in Africa 1870-1960}

Volume 2

\section{The History and Politics of Colonialism, 1914-1960}

Edited by L. H. GANN and PETER DUIGNAN

A collection of the best papers on the later colonial years which examines records that have recently been found in European and African archives. '.. a fascinating selection of different points of view.' The Economist

\section{Volume 3}

\section{Profiles of Change}

\section{African Society and} Colonial Rule

\section{Edited by}

\section{VICTOR TURNER}

Examines the impact of complex alien economic, social, political and religious forces on the indigenous societies of Africa.

f5 net

CAMBRIDGE UNIVERSITY PRESS

\section{Reaction to}

\section{Colonialism}

A prelude to the politics of independence in Northern Zambia 1893-1939

\section{H. S. MEEBELO}

The author maintains that the African independence movement can no longer be regarded as a phenomenon which arose during or after World War II, as it was essentially the end product of political evolution which had taken place before the war.

Published for the Institute for Social Research, University of Zambia.

Cloth E2.40; paper $£ 1.20$ net

\section{Strategy and}

\section{Transaction in an African Factory}

African workers and Indian management in urban Zambia

\section{B. KAPFERER}

Presents an analysis of the patterns of social behaviour among a group of African workers in a factory set in the changing social and political context of postindependent Zambia. The major emphasis of the book is to apply the social exchange theory, in particular propositions derived from it, in explaining changing patterns of behaviour in the factory.

About 13.60 net

MANCHESTER UNIVERSITY PRESS 


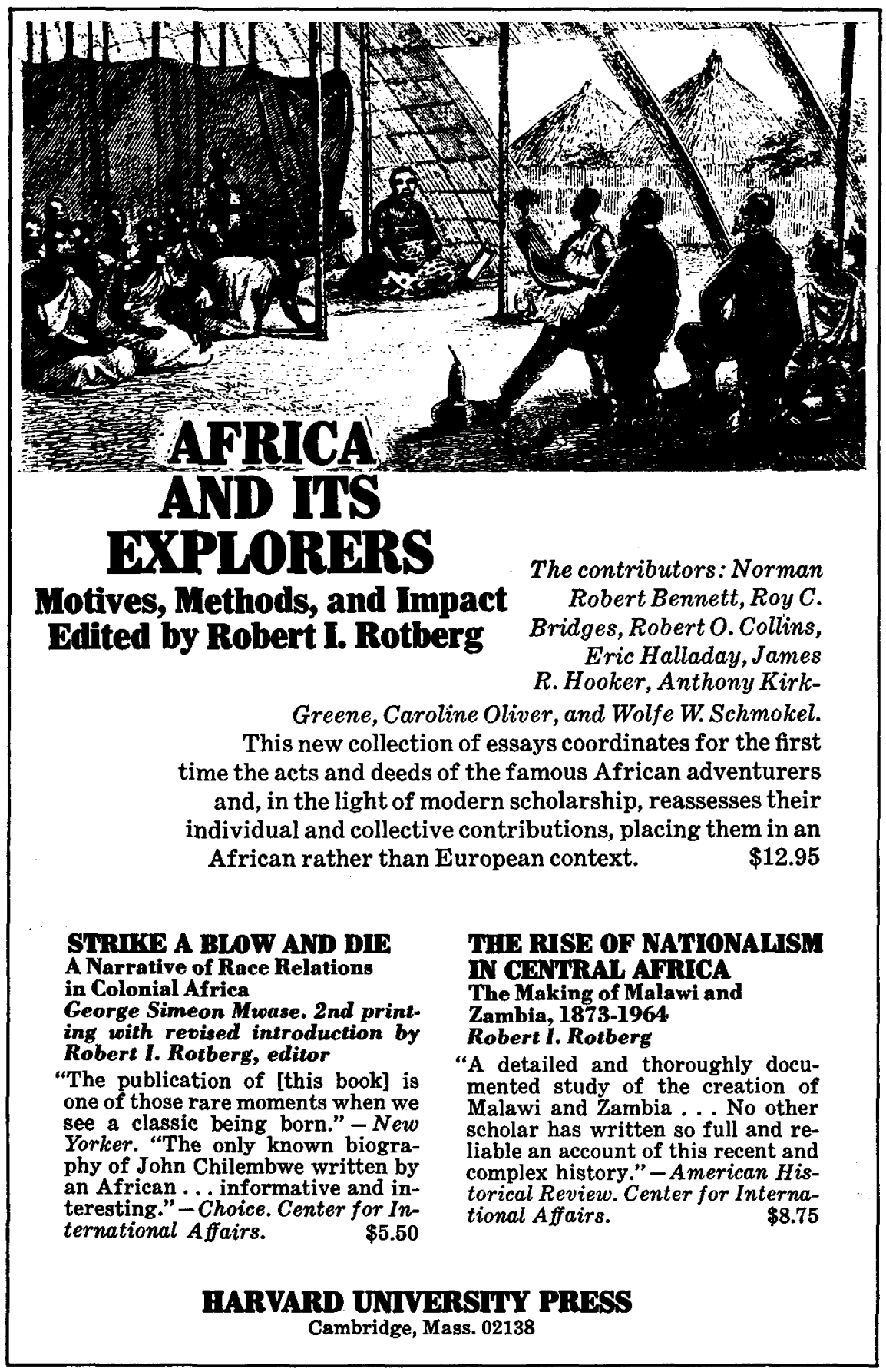

(vii) 


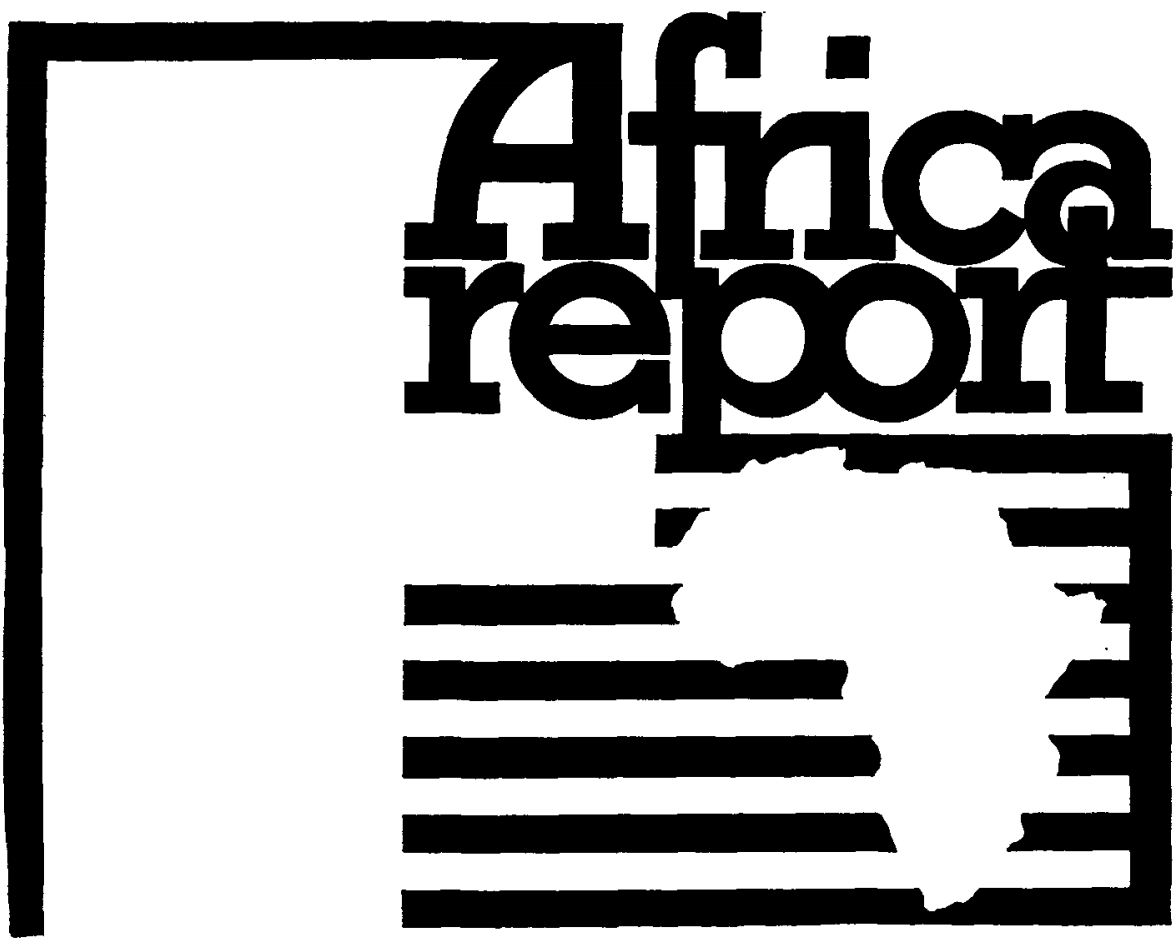

What's Happening in Africa? Whether it's Politics, Social Change,

Economics, Science or the Arts - Keep in Touch with the Events,

Ideas, Personalities and Trends that are Transforming a Continent.

SPECIAL OFFER: One-year introductory offer of $\$ 5.00$ to new subscribers covers nine issues and an index. Normal regular mail subscription $\$ 8.00$.

TO SUBSCRIBE: Please check box below and use coupon to print your name and address.

Cut along dotted line

\section{AFRICA REPORT}

530 DUPONT CIRCLE BUILDING

WASHINGTON D.C. 20036

[ ] please enter $\$ 5.00$ introductory subscription. Check enclosed.

[ ] please send free specimen copy without obligation.

NAME

ADDRESS

zip code 


\section{UNIVERSITY OF ZAMBIA Institute for Social Research}

(formerly Rhodes-Livingstone Institute)

P.O. Box 900, Lusaka, Zambia

PUBLICATIONS : African Social Research (bi-annual journal): Zambian Papers (annual) Communications (annual).

AFRICAN SOCIAL RESEARCH No. 10

December 1970

Pre-Colonial Trade in Zambia by ANDREw D. ROBERTS

Red Soils in Rhodesia by ROBIN H. PALMER

REVIEW ARTICLES:

Advanced Geography Texts for Developing Africa: The Changing Scene by D. HYWEL DAVIES

Lévi-Strauss comes to Africa, Speaking English by ADAM KUPER

Reviews by ANDREW D. ROBERTS, J. E. G. SUTTON, H. W. LANGWORTHY, E. R. TURTON, EZEKIAL MPHALELE, V. SUBRAMANIAM, G. P. MCGREGOR, R. J. FIELDER, VALDO PONS, NICOLAS WINCOTT

SUBSCRIPTIONS:

Category A: African Social Research, (2 issues), Zambian Papers (1 issue) K3, £1.75, U.S. \$4.25 per annum.

Category B: As A plus I.S.R. Communications (1 issue) K4, £2.33, U.S. \$5.65.

Single issues: $K 1.25,73 \mathrm{p}, U . S$. $\$ 2.00$. Communications related to cost of production.

All correspondence and books for review should be addressed to the Publications Officer

\section{JOURNAL OF \\ COMMONWEALTH POLITICAL STUDIES}

Vol. VIII No. 3

November 1970

Intra-regional Factionalism and Coalition - building in West Bengal by Marcus $F$. Franda

Mr de Valera's Dominion: Irish Relations with Britain and the Commonwealth, 1932-1938

by David Harkness

The Western Nigeria Civil Service through Political Crises and Military Coups

by D. 7. Murray

White Attitudes and the Unilateral Declaration of Independence:

A Case Study

by Richard Hodder-Williams

Annual subscription rate $f_{2.75}$. Single issues $£_{11.13}$

LEIGESTER UNIVERSITY PRESS

University, 2 University Rd, Leicester LEI ${ }_{7}$ RB. England 


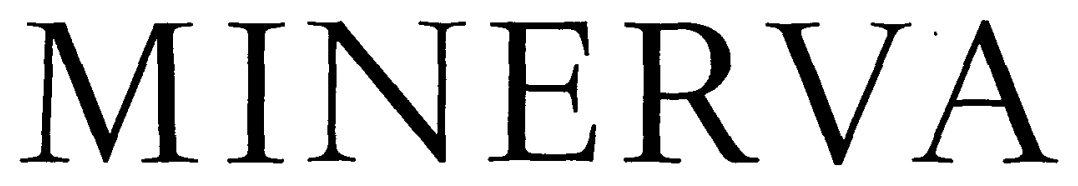

A Review of Science Learning and Policy

The Political University and Academic Freedom

\section{ARTICLES}

Sponsored Research and University Budgets: A Case Study in American University Government Frederick Betz and Carlos Kruytbosch

Bombay Colleges Philip G. Altbach

American University Teachers and Opposition to the Vietnam War Everett Carll Ladd

Scientific Organisation and Science Policy in Imperial Germany, 1871-1914: The Foundation of the Imperial Institute of Physics and Technology Frank Pfetsch

REPORTS AND DOCUMENTS

University Reform in Japan

\section{CORRESPONDENCE}

Letters from Eric Hutchinson, Jacques Waardenburg, Terry N. Clark

$$
\text { BOOK REVIEWS }
$$

Reviews by Austen Albu, Hugh Thomas, Edmund Ions, Edward Shils 


\section{LUGY C. BEHRMAN}

\section{ANN BEGK}

\section{ROBERT LEGVOLD}

\section{AUDREY G. SMOGK}

\section{MUSLIM BROTHERHOODS AND POLITICS IN SENEGAL}

The influence of traditional and religious groups on modern politics is a significant factor in the development of many countries. Focusing on the West African country of Senegal, Mrs. Behrman investigates the political roles of Muslim religious organizations there. She analyzes the historical conditions under which Muslim brotherhoods emerged as a political force and examines their contemporary function in Senegalese politics. $\$ 7.25$

\section{A HISTORY OF THE BRITISH MEDICAL ADMINISTRATION OF EAST AFRICA, 1900-1950}

Mrs. Beck's account of the modernization and development of scientific health services in Kenya, Uganda, and Tanganyika in the first half of the 2oth century provides the first comprehensive evaluation of the British medical administration and its relation to the conduct of East African colonial governments. Commonwealth Fund. $\$ 8.00$

\section{SOVIET POLIGY IN WEST AFRICA}

In this first in-depth study of Soviet relations with Black Africa, Mr. Legvold focuses on six West African countries that differ widely in their approach to foreign aid and domestic matters-Guinea, Ghana, Mali, Ivory Coast, Senegal, and Nigeria. He explores the intricacies of Soviet policy in Africa and follows closely its course over the ten years after the majority of that continent's colonies achieved independence. \$13.00

\section{IBO POLITICS}

\section{The Role of Ethnic Unions in Eastern Nigeria}

The first social scientist concerned with Africa to obtain both primary records of ethnic unions and interviews from their leaders and prominent members, Mrs. Smock demonstrates that ethnicity is not a legacy of the precolonial past so much as a response to forces of change induced by colonial rule. She concludes that ethnic unions are a sign of modernization, not backwardness. \$10.00

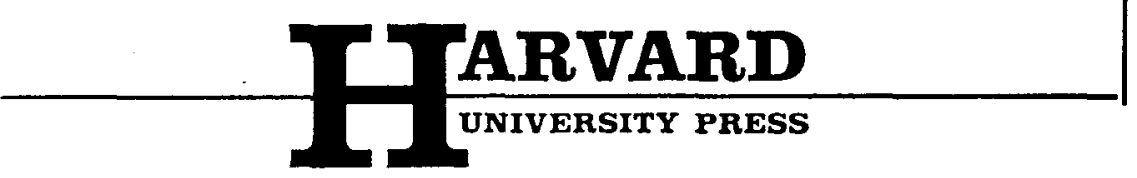




\section{Nuer Religion}

\section{E. E. EVANS-PRITCHARD}

This book was written not only to complete Professor EvansPritchard's general ethnographic account of Nuer modes of livelihood, but also as a self-contained study of a primitive religion. First

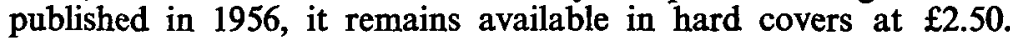
16 plates 5 text-figures paper covers $£ 1.25$

\section{Oxford History of South Africa}

Volume II, South Africa 1870-1967

Edited by MONICA WILSON and LEONARD THOMPSON Volume II of a two-volume history of South Africa describes the economic growth that has taken place in South Africa during the century that began with the discovery of diamonds in Griqualand West; examines the history of the three great social complexes of modern South Africa; deals with the impact and interaction of the major political forces that have operated in and on South African society during the century, and presents an account of the changing relationships between South Africa and the outside world. 13 textfigures 6 maps $£ 5$

\section{Liberalism in South Africa 1948-1963}

\section{JANET ROBERTSON}

Since the Second World War a minority of South Africans - white as well as black - has actively sought to extend equal rights to nonwhites within the parliamentary system. This book describes what happened to liberals working within such groups as the African National Congress, the United Party, the Liberal Party, and the Progressive Party, and tells the story of the dismantling of the liberal state and the failure of the liberal ideal in South Africa. $£ 2.25$

\section{Crisis and Conflict in Nigeria}

A Documentary Sourcebook 1966-1970

Volume I: January 1966-July 1967

Volume II: July 1967-January 1970

\section{A. H. M. KIR K-GREENE}

These volumes of over 200 contemporary documents, accompanied by a detailed narrative text, provide the first close chronology of the four years of crisis, and offer an essential basis for anyone wishing to make a scholarly and objective assessment of the events that led up to the secession of Biafra and the subsequent civil war.

Volume I 6 illustrations 1 map $£ 4.25$

Volume II 7 illustrations 2 maps $£ 5.25$ 


\section{Two new titles in the Ibadan History Series}

POWER AND DIPLOMACY IN NORTHERN NIGERIA 1804-1906 The Sokoto Caliphate and its

\section{Enemies}

\section{R A Adeleye}

The rise and fall of the Sokoto Caliphate, the largest of the nineteenth century states in West Africa, had far-reaching consequences - political, religious and cultural - for the whole of Nigeria. This study, the most comprehensive yet attempted, uses French, Hausa, Arabic and English sources to unfold and analyse the internal and external influence behind the establishment of the Caliphate in the early nineteenth century, its uneasy relations with its neighbours and its ultimate conflict with and conquest by the British colonialists.

0582645166

£3.50 net

\section{REVOLUTION AND POWER POLITICS IN YORUBALAND 1840- 1893}

\section{Ibadan Expansion and the Rise of Ekitiparapo \\ S A Akintoye}

In the history of most African peoples, the nineteenth century was an era of revolutions. Few were more profound in their effect than the revolution which, through a series of wars between 1820 and 1893, transformed the face of Yorubaland; the complexities of the Yoruba political structure, demography and pattern of local loyalties are rooted in this upheaval. This book marks the first attempt to place in the historical perspective of the Yoruba, the history of the eastern communities about which little or nothing has so far been written.

0582645336

$£ 3.25$ net

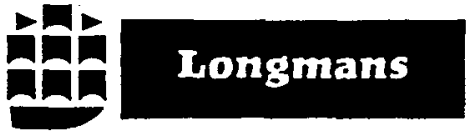


The Journal of Modern African

\section{Studies}

is one of over $\mathbf{5 0}$ learned journals published by Cambridge University Press.

A descriptive catalogue of Cambridge journals including details of back volumes is available from the London and New York offices of the Press.

Cambridge journals may be ordered from a bookseller or direct from the publishers.

\section{Cambridge University Press}

Bentley House, 200 Euston Road London NW1 2DB

American Branch: 32 East 57th Street New York, N.Y.10022
NEW FROM METHUEN

Studies in African History

THE NIGERIAN

ARMY

\section{$1956-1966$}

\section{N. J. Miners}

In January 1956 only fifteen of the 250 officers in the Nigerian Army were Nigerian, and the soldiers were generally despised by nationalists as the underpaid and poorly equipped agents of the colonialists. Ten years later, on the eve of the first military coup, the army had been modernized and expanded, had served with distinction in the Congo, and all its officers were Nigerian. N. J. Miners traces the stages of this transformation and describes the increasing tension and political manoeuvring which exploded into the military coups of 1966.

$£ 2.25$; Paperback: $£ 1.40$

\section{The Politics of Trade Negotiations between}

\section{Africa and the European Economic \\ Community}

\section{The Weak Confront the Strong}

\section{WILLIAM ZARTMAN}

How do the weak negotiate with the strong and win some benefits in spite of their lack of power? Discussing negotiations between the EEC and African states in the I960's, Professor Zartman examines the political dynamics of the process, in theory and in practice.

\section{Princeton University Press}

Princeton, New Jersey o854o 


\section{Journal of African History}

Volume XII part 11971

EUGEN STROUHAL Evidence of the early penetration of Negroes into prehistoric Egypt

PHILIP D. CURTIN Jihad in West Africa: early phases and inter-relations in Mauritania and Senegal

R. C. C. LAW The constitutional troubles of Oyo in the eighteenth century

TOM w. SHICK A quantitative analysis of Liberian colonization from 1820 to 1843 , with special reference to mortality

MARTIN Z. NJEUMA Adamawa and Mahdism: the career of

Hatatu ibn Sai'd in Adamawa, 1878-1898

RAYMOND DUMETT The rubber trade of the Gold Coast and Asante in the nineteenth century: African innovation and market responsiveness

F. K. EKECHI Colonialism and Christianity in West Africa: the Igbo case, 1900-1915

KENNETH KING The Kenya Maasai and the protest phenomenon, 1900-1960

HENRI BRUNSCHWIg Scramble et 'Course au Clocher'

f1.50 net (\$4.75 in U.S.A.)

Annual subscription $f 5$ net

(\$17.00 in U.S.A.) for four issues

CAM BRIDGE UNIVERSITY PRESS

P.O. Box 92, London NW1 2DB

\section{NIGERIA}

\section{Crisis and Beyond}

\section{John Oyinbo}

with an introduction by
John P. Mackintosh, M.P.

The author's perspective of events in Nigeria before, during and after the civil war is that of an expatriate whose involvement with the country began in childhood. His book begins on 1 October 1960, when Nigerians celebrated independence, and traces the change from their initial delight to the disillusionment of subsequent years, when discontent and suspicion culminated in the breakdown of a political machine which could not cope with the pressures put on it. In January 1966 a new military government announced it had taken control after the attempted revolt by certain army officers. The author lived with Nigerians through the events which followed-counter coups, massacres, Gowon's creation of states, Ojukwu's announcement of secession, the final tragedy of civil war - and his experiences enable him to offer this analysis, which he concludes with an assessment of the country's prospects for achieving a new and stronger national unity.

E2.50

\section{WORLD}

\section{DEVELOPMENT HANDBOOK}

\section{Juliet Clifford and Gavin Osmond}

Many of the people who would like to become involved in improving the conditions of those living in poverty are deterred by the complexity of the issues in the subject of aid for overseas development. World Development Handbook is a layman's introduction to economic development, and deals mainly with the effects that rich countries' policies have upon the economies of poor countries. The book is in four main parts: 1. The problem of poverty; II. Development; III. The economic relationship between rich and poor countries; IV. International aid. The work naturally contains a wealth of statistical information, but principally this is a book about ideas and policies concerning aid for developing countries.

22.25 hard cover

Q1.50 soft cover

CHARLES KNIGHT \& CO LTD, 11-12 Bury Street, London EC3A 5AP Telephone orders to: 01-626 5477, or Tonbridge 61216 


\section{CAMBRIDGE UNIVERSITY PRESS}

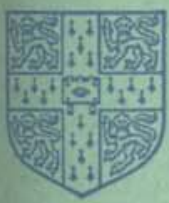

Bentley House, 200 Euston Road, London NW1 2DB

American Branch: 32 East 57th Street, New York, N.Y.10022

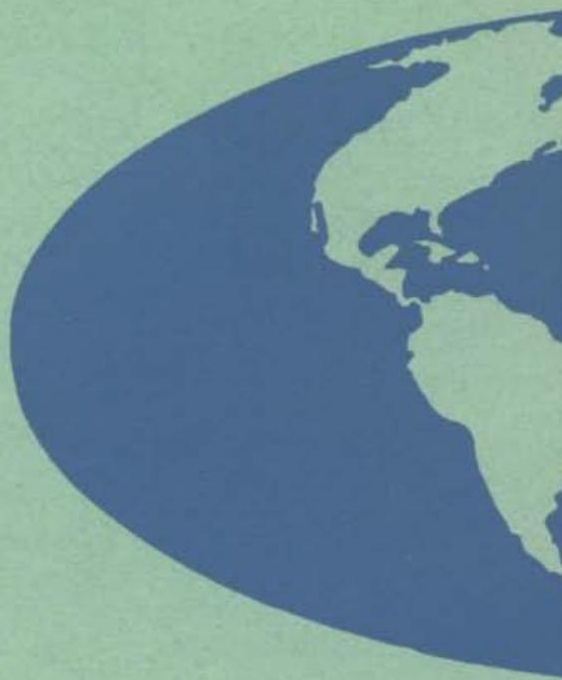

$£ 1.30$ net $\$ 4.00$ in U.S.A. Subscription Price $£ 4.00$ net $\$ 12.50$ In U.S.A. 


\section{THE JOURNAL OF MODERN AFRICAN STUDIES}

The Journal offers a quarterly survey of politics, economics, and related topics in contemporary Africa.

The main emphasis is upon the peoples and policies, the problems and progress of this dynamic and disparate continent; upon the many societies that are evolving rather than the essential characteristics of the old; upon the present, not on the more distant past. The best current work is sought from specialists in different academic disciplines, whose contributions can illuminate and crossfertilise one another.

The Journal seeks to promote a deeper understanding of what is happening in Africa today. It is intended for both the political scientist and the practical politician, the administrator and the advocate, the economist and the educator, the banker and the businessman, the diplomat and the technocrat, the civil servant and the nationalist leader. All have something to contribute to these pages and, it is hoped, much to learn from them.

Editorial policy avoids commitment to any political viewpoint or ideology, whether imperialism, pan-Africanism, capitalism, socialism, or nationalism. Such concepts, however, have relevance to the modern African situation, and merit serious discussion, often from several different points of view, in order that controversial issues may be fairly examined.

Contributors of accepted articles will be asked to assign their copyright, on certain conditions, to Cambridge University Press, to help protect their material, particularly in the U.S.A. 